\title{
FINANCIAL CONGLOMERATE IDENTIFICATION BY FINANCIAL MARKETS REGULATORS: CASE OF DEVELOPED AND EMERGING MARKET ECONOMIES
}

\author{
Natalia Kuznetsova $^{1}$, Zhanna Pisarenko ${ }^{2}$, Liudmila Lobanova ${ }^{3}$ \\ ${ }^{1,2}$ Faculty of economics, St. Petersburg State University, 62 Chaikovskogo Str., \\ Saint-Petersburg, Russian Federation \\ ${ }^{3}$ Faculty of Business Management, Vilnius Gediminas Technical University, \\ Sauletekio al. 11, Vilnius, Lithuania \\ E-mails: ${ }^{1}$ nataliakuz2010@yandex.ru; ${ }^{2 j a n n a 12000 @ y a n d e x . r u ; ~}$ \\ 3liudmila.lobanova@vgtu.lt (corresponding author)
}

\begin{abstract}
The paper examines financial conglomerates as an innovative form of integration from different sectors of the world financial market. The authors reveal their features, advantages and risks. The goal of the paper is an empirical cross-country analysis of financial conglomerate identification by financial markets regulators. There is no common approach to such a consolidated entity as financial conglomerate among both researchers and regulators. The blurring of the dividing lines between financial sectors is of great importance too. The development of a conceptual apparatus, the theory and analysis of a financial conglomerate has become of considerable importance.
\end{abstract}

Keywords: financial convergence, financial conglomerate's identification, financial market supervision, emerging financial market economies comparison.

JEL Classification: G10, G20, G23.

\section{Introduction}

The modern global trend in development financial services industry is characterized by the growing convergence and blurring of the dividing lines between financial sectors. The largest banks and non-bank institutional investors such as: insurance undertakings, investment corporations and pension funds has begun to form financial conglomerates. They work globally and gain an enormous market power compared to a state power. The structure, owners of these multinational financial groups are veiled, their interrelations are confused, and hence the increasing attention of scientists, regulators and international organizations to these institutions is understandable.

The success of new forms of financial integration among financial entities from different sectors was determined by the processes of globalization and liberalization, which remove the barriers to the integration of the world financial markets (Kuznetsova, Pisarenko, \& Chernova, 2016; Beck \& Casu, 2016; Peleckienè, Peleckis, \& Dudzevičiūtè, 2011; Kuznetsova \& Chernova, 2001), and by the technological and financial innovations (Amel, Barnes, Panetta, \& Salleo, 2004; Berger, Hasan, \& Zhou, 2010; Goddard, Molyneux, Wilson, \& Tavakoli, 2007; Allen \& Santomero, 2001; Schmid \& Walter, 2009; Staikouras, 2006).
The revenues of the largest financial conglomerates can be compared with the budgets of the leading countries in the world. Thus, according to Global Justice, in 2000, out of the world's 100 largest economic entities, 51 were the global corporations, 49 were the states. There were 69 corporations and 31 countries among top 100 were in 2017. 20 global corporations from 69 belong to financial sector. According to the USA FRS (Federal Reserve System) data by the end of 2017 the number of American commercial banks with consolidated assets more than $\$ 300 \mathrm{mln}$. reached 1816. Their aggregate assets were $\$ 15,427,246 \mathrm{mln}$. compared to $18,3 \mathrm{trln}$. of the USA GDP in 2016 (Global Fortune 500..., 2016).

An active debate is going on about the structure, risks and cost effectiveness of such types of association. Schmid and Walter (2009) argue that the conglomeration renders negative influence on financial company's value and its competitive advantages on the market. Other researchers find arguments that financial conglomeration gives advantages during turbulent times of economic recession and high risk exposure. The influence of globalization, economic crises, disparity of economic development on convergence were studied by Atkinson and Micklewright (1992), Kose, Prasad, Rogoff, and Wei (2009); Ozcan, Manganelli, 
Papaioannou, and Peydró (2008); Duflo and Saez (2002); Peleckienè et al. (2011), etc.

Financial globalization is a part of the entire globalization process and forms the global financial market. The beginning of full-scale financial globalization, according to most researcher's vision is considered the active external expansion of national banks and the formation of the first transnational banks (TNBs) in the XX century 90th, which grew in the beginning of the XXI century into the largest international associations - financial conglomerates.

New synthetic institutions operating in different sectors of the global financial market under different brands - financial conglomerates - use financial convergence to gain competitive advantages on financial markets. The financial convergence could be conceived as a tool for competitive struggle (Chernova, Pisarenko, \& Kuznetsova, 2016).

As a result there are financial and industrial holdings, combining banking, investment pension, insurance, leasing activities, as well as other, including non-financial activities on the market. It is obvious that without providing full-fledged consolidated supervision it is impossible to see the full picture of the financial stability of the financial conglomerate as a whole or its individual members, to identify and properly evaluate the possible risks and offer their optimal regulation. The organizational structure of financial supervision has been changed in most developed countries of the world. The urgent task for emerging economies is the development of regulatory and supervision mechanisms for large financial institutions. At the same time, the regulatory environment should not interfere business development of financial institutions, as well as opportunities to provide modern services to economic entities and households.

During the upper point of the 2007 financial crisis, the movement of assets within corporate groups and the obligations of financial intermediaries distorted the supply of capital and significantly disrupted the economic systems. Such a systemic failure is usually attributed to (a) a general shock of assets (for example, mortgages, shares, etc.), (b) contamination (e.g. investor psychology, panic, etc.) and/or (c) excessive interconnection between financial intermediaries, (d) the funding maturity (Brealey, Myers, Allen, \& Mohanty, 2012).

Despite the fact that the deep roots of the 2007 global economic crisis are still being dis- cussed, many researchers agree that it was the excessive diversification of banking activities in other sectors of the economy, together with the increase in the number of large, complex and interconnected financial conglomerates, that served as a catalyst for the systemic collapse scenario implementation. Therefore, the issue of effective regulation and supervision of systemically important financial institutions (SIFIs), is one of the central points in scientific discussions and regulatory initiatives (Beck \& Casu, 2016; Elyasiani, Staikouras, \& Dontis-Charitos, 2016).

The goal of the paper is an empirical crosscountry analysis of financial conglomerate identification by financial markets regulators. The choice of countries - emerging market economies (in the context of comparison with the developed economies) - is predetermined by different types of regulation and financial legislation under consideration. The relevance of the paper is preconditioned by the fact that there is no unique structurally logical system of financial conglomerate model. A definition of a financial conglomerate is important for all regulators of financial markets. It is necessary to distinguish this group from other groups of entities. The structure of group and areas of activities that a financial conglomerate may be engaged in are also important. The absence of the sound system regulation and supervision of such financial conglomerates, different understanding of these undertakings by regulators (financial conglomerate, financial group, financial holding, financial-industrial group, etc.) cause significant uncertainty, so far as risks are extremely large particularly for the governments and their exposure is very probable. Hence, the subject of this paper supposed to be very relevant.

\section{Financial conglomerates identification in developed countries (EU countries, UK, USA, Japan)}

\subsection{Supervisory authorities' financial con- glomerates general vision}

The most important task for financial regulation is the prevention of systemic crises and idiosyncratic shocks, since they lead to loud bankruptcies of large complex financial structures, which assets are larger than their home countries GDP. Undoubtedly, their bankruptcy could lead to sovereign defaults, since the main burden on saving such institutions rests on the home state. The situation is aggravated by the fact that financial conglomerates specialize in providing a wide range of 
financial services that affect the interests of both business and the state, as well as socially significant activities such as insurance, pension planning, etc.

Identification of financial conglomerates is developing at different levels: international (at the level of international organizations), regional (at the level of the EU) and the state (at the level of individual states). The European Union has the most developed regulatory framework for financial conglomerates.

International level. At the international level, a clear definition is identified by The Joint Forum. The Joint Forum under the aegis of the Basel Committee on Banking Supervision (BCBS), the International Organization of Securities Commissions (IOSCO) and the International Association of Insurance Supervisors (IAIS) in 2001 gave definition of Financial conglomerate as following: any group of companies under common control whose exclusive or predominant activities consists of providing significant services in at least two different financial sectors (banking, securities, insurance).

Financial Stability Board (FSB) in 2011 introduced the concept of "Large Complex Financial Institutes" (LCFIs). Since 2011 lists of global systemically important financial institutions has been compiled and published annually. In 2017 this list included 30 biggest world banks (depending from the level of risk of global losses global systemically important banks are divided into five subgroups) and nine global systemically important insurers. All financial institutions included in these lists are financial conglomerates.

Other international organizations (the Group of Twenty - G-20; Financial Stability Board) contributing to the identification of financial conglomerates and the development of their regulation and supervision models rely on the definition of The Joint Forum. But the solutions of the Joint Forum are advisory.

There is no universally recognized opinion, what the architecture of regulation and supervision of financial conglomerates is the best possible. But it is necessary to create an international system of institutions controlling the activities of the FC. The most likely candidates are the G20, the Financial Stability Board (FSB) and The Joint Forum.

\subsection{EU financial conglomerates supervisory activities}

The European Union has the most developed legal framework for financial conglomerates. The Directive on Financial Conglomerates (The Article 2(14) of the Directive 2002/87/EC of the European Parliament and of the Council) stipulates a financial conglomerate as a group of companies that operate in different sectors of the financial market. "At least one of the entities in the group is within the insurance sector and at least one is with the banking or investment services sector; the consolidated and/or aggregated activities of the entities in the group within the insurance sector and the consolidated and/or aggregated activities of the entities within the banking and investment services sector are both significant within the meaning of the Directive's Article 3 (Directive 2002/87/EC of the European Parliament and of the Council). This definition is not currently legislated, but is used to organize working groups on financial conglomerates. The definition should highlight the special role of insurers, as well as a fairly free list of participants in the conglomerate (Hartmann, Maddaloni, \& Manganelli, 2003; Kalemli-Ozcan, Manganelli, Papaioannou, \& Peydró, 2008). The previous definition of financial conglomerate (prior to amending Directive 2002/87/EC in 2012) differed in that an exhaustive list of possible participants in the financial conglomerate was provided.

The changes introduced in the definition reflected the increased role of the insurance sector and the emergence of new players in the financial market that become participants in financial conglomerates (Schoenmaker \& Véron, 2016). Moreover, annually the EU regulators, The Joint Committee of the European Supervisory Authorities (ESAs) - EBA, EIOPA and ESMA publish annually a list of the largest financial corporations that are recognized as officially existing financial conglomerates. The 2017 list identified 80 financial conglomerates with head of group in the EU/EEA (List of Financial Conglomerates, 2017).

According to the European classification of conglomeration, a group of companies is viewed as a financial conglomerate, if more than $50 \%$ of the group's assets are financial or if in a group of companies from 10 to $90 \%$ of operations are bank and insurance transactions. Even if the group's other (non-financial) activity in the balance sheet of the group has indicators of more than 6 billion Euros, such a group of companies is also viewed 
as a financial conglomerate. If a group of companies is managed not by a legal entity (but by some other structure), it is supposed as a mixed financial holding company.

\subsection{United Kingdom financial conglomerate regulator's consideration}

The most traditional approach in this country belongs to the Bank of England, which pays special attention to companies that occupy leading roles:

- in the activity of signing share issues;

- in the activity of signing bond issues;

- on the issue of syndicated loans;

- on derivatives issue;

- on currency trading;

- in the field of trust management of securities.

A financial institution that meets the requirements of the above list can be called a financial conglomerate, but only in its most general form. In official Bank of England publications, it is referred to as a "large complex financial institution" (Bank of England, Financial Stability Review, 2003). As can be seen from the above points, the main focus is pointed on the securities sector, which is more consistent with the operations of the universal bank.

\subsection{USA authorities vision}

There are more than 115 federal and state agencies regulating various aspects of financial services in the USA. At the state level, consolidation of regulators of different segments of the financial market (insurance, banking, investment) has already begun. Additionally, in each state at the local level there is a ramified system of agencies and commissions. Prior to the ongoing reform of financial conglomerate regulation, $\mathrm{FC}$ were subordinate to the FRS, the US Treasury control Department of the Ministry of Finance, the Securities Commission, and the state's regulators where they were registered (Bhatia, 2007; Brown, 2005).

Which federal regulator should oversee the activities of financial conglomerates depended directly on whether there was a depository institution in the conglomerate and what type of deposit institution it was. Deposit institutions include commercial banks, savings banks, credit unions and industrial banks. The basis of the above-mentioned institutions is the attraction of deposits and the issuance of loans. The difference lies in the structure of ownership, the range of services offered and, accordingly, the requirements of regulators.

In some cases, US financial conglomerates do not fall under the influence of either federal or local regulators. If there is no commercial or savings bank in the conglomerate structure, but there are other financial companies (for example, investment companies, insurance companies, etc.), it is not subject to consolidated supervision. Separate subsidiaries in this case are regulated on a functional basis.

According to the principles of functional regulation, the regulator concentrates on regulating a certain category of financial products or services that a financial company or holding company provides, rather than at the financial institution itself. Berkshire Hathaway Inc. is an example of a large financial conglomerate (about $80 \%$ of profits in 2015 is gained from financial services), which is not subject to regulation on a consolidated basis. Insurance companies that are part of the corporation are regulated by the laws of the state they conduct insurance operations (Final Report on the Peer Review on Freedom to Provide Services, 2016).

The issue of consolidated regulation of financial conglomerates after the collapse of Enron Corp. has acquired special importance in 2001 in the USA. At the heart of this high-profile case was the conglomerate Citigroup, at that time one of the largest in the country. All parts of such an association are so closely interact that a serious unpredictable failure in the activities of either of them (in this case it was Citibank) leads to long-term negative consequences for all, without exception, other structural elements. The structure of the corporation was designed in such a way that, despite the control of the corporation over more than a dozen financial and investment companies in the US and around the world, and more than $7 \%$ of the profits derived from the derivatives trade, it did not come under consolidated control. In addition, Enron Corporation had many off-balance transactions (about 3,000 partnerships and subsidies).

None of these groups had the authority, jurisdiction or resources to ensure the systematic sharing of information between all of holding company regulators and the relevant functional or institutional regulators. As a result, it was difficult for the plethora of agencies to coordinate their activities and to assess the systemic risks to the financial industry as a whole. In fact, inter-agency rivalries had undermined efforts to expand the scope and composition of these groups in order to provide that kind of strategic assessment of the financial industry's risks.

The Act established uniform minimum capital adequacy standards The Dodd-Frank Act established one set of minimum capital requirements for insured depository institutions, BHCs, 
and nonbank financial companies subject to supervision by the Federal Reserve System. In 2010, measures were taken in the United States to modify the existing regulation: the Dodd-Frank Act "On the Reform of Wall Street and Consumer Protection" was adopted (Chaffee, 2010). Its main goal is to solve problems related to the regulation of large financial institutions. The Act was established by the Federal Reserve System. The DoddFrank Act established one set of minimum capital requirements for insured depository institutions, $\mathrm{BHCs}$, and non-banking financial companies.

The prior to 2010, USA regulatory regime required lower minimum capital adequacy requirements for large financial services holding companies. They were supervised on consolidated basis and had substantial competitive advantages of financial services holding companies over Banking Holding Companies. After The Act was adopted FRS (Federal Reserve System) got right to set strict requirements for both generally applicable minimum leverage capital requirements and the generally applicable risk-based capital. In addition, the largest USA banks will probably not be allowed to use their own internal risk models that would allow them to operate with lower minimum risk-based capital requirements than smaller banks. This will enhance the competition on the USA financial market in the nearest future.

The Dodd Frank Act states that the levels for these two requirements on July 21, 2010 serve as a floor and prohibits the Federal Reserve System from reducing these requirements below their levels on July 21, 2010. The Act allows the Federal Reserve System to set higher amounts for both generally applicable minimum leverage capital requirements and the generally applicable riskbased capital requirements than the levels that they were on July 21, 2010 (Chaffee, 2010). The advantage of this requirement is that all holding companies for financial services that are systemically important will be required to meet the same, minimum capital adequacy requirements. As a result, these holding companies will be on a level playing field in terms of competition. As noted above, under the prior regulatory regime, CSEs had a competitive advantage over FHCs and BHCs because of the weaker capital requirements imposed on them by the SEC than the requirements imposed on FHCs and BHCs by the Federal Reserve. In addition, if the Federal Reserve becomes captured by the financial conglomerates that it supervises, this measure will prevent those conglomerates from using their influence over the Federal Reserve to undermine capital adequacy standards completely because the Federal Reserve does not have complete discretion on the required levels due to this provision in the Act (Federal Law No. 208-FZ of December 26, 1995). Another effect of this provision is that the largest banks in the United States will probably not be allowed to use their own internal risk models that would allow them to operate with lower minimum risk-based capital requirements than smaller banks. The Federal Reserve, the OCC, and the FDIC currently are considering adopting a rule to that effect (Kushmeider, 2005). If such a rule is ultimately adopted, it will also allow small banks to compete with larger banks on a more level playing field in the future. As a result, banks and other financial institutions may not feel pressured as much to merge as they would have if the advanced risk-based capital adequacy standards that the federal banking regulators originally adopted under Basel II were left in place. Without this pressure, fewer financial institutions may join the ranks of the "too big to fail" firms because they no longer think that they must in order to remain competitive.

\subsection{Japan regulators' financial conglomerates understanding and reformation}

The government of Japan pays special attention to financial conglomerates (Guideline for Financial Conglomerates Supervision, Japan, 2005). It is important to note that it is Japan that can be considered the cradle of this type of institutions: right after the Meiji revolution, large groups of enterprises, known as "zaibatsu", formed on the territory of this state. By the middle of XX century traditional trading houses acquire the character of financial groups. Akio (2007) notes the leading role in the management of this type of associations of financial sector enterprises, which allows them to be considered as prototypes of modern financial conglomerates.

The interpretation of the term financial conglomerate should be considered in accordance with the rules of the Japanese FSA (Financial Services Agency Organization Rules). "A financial conglomerate is a corporate group that includes the following areas of activity: insurance business, banking business, securities transactions, trust management or investment and consulting business" (Basic Concepts concerning Financial Conglomerates Supervision..., 1998). However, this approach represents a conglomerate as a group of organizations, focusing on the group.

In Japan, the following types of financial conglomerates are distinguished: 
- financial holding company "Financial Holding Company Group" (according to the legislation (Japan, art. 2 par.13 of the Banking Law), these include the Bank Holding Company "Bank Holding Company", Long-term Credit Banking Holding Companies "Bank Holding Company", "Insurance holding companies" Insurance Holding Company", carry out operations of at least two types: banking, insurance, securities transactions);

- De-facto Holding Company Group, a de facto holding company; "The de facto holding company is not a financial holding company. This is a non-financial institution, whose subsidiaries are financial institutions and are involved in at least two types of financial activities";

- the parent company of financial intermediaries (Financial Institution Parent Company Group);

- a foreign holding company (group) (Foreign Holding Company, etc. Group).

Let us note that the classification of the Japanese regulator is based on the ability of the group to influence the financial stability of institutions located within Japan. The definition used, unlike the British one, is excessively broad and allows putting almost all large financial and industrial groups under the legal control of local regulators. This approach corresponds to the tradition of protectionism in Japan and the regulatory model (called "restriction of market mechanisms"), adequate oligopolistic structure of the financial market of the country.

\section{Identification of financial conglomerates in emerging market countries (case of Russia and Lithuania)}

\subsection{Identification of financial conglomerates in Russia}

The legal definition of "financial conglomerate" in the Russian Federation is absent. As a result, financial groups appear in the market, combining banking, investment, insurance activities are regulated as separate financial companies. Obviously, without a full-fledged consolidated supervision of these groups, it is impossible to see the full picture of the association's financial stability as a whole or its individual participants, to identify possible risks and propose their optimal regulation.

During the period of 1993-2007 there was a legal definition for financial - industrial groups
(FIG) in Russia. In 1998, there were officially 74 FIGs in the Russian Federation, including 9 transnationals. However, in 2007, the law on FIGs lost its force in the framework of the administrative reform. Since 2007 completely new corporate structures have appeared in Russia. Despite the ongoing wave of mergers and acquisitions, the emergence of large financial groups in the country, the development of regulation and understanding of financial conglomerates in the Russia is clearly lagging behind.

The Civil Code of the Russian Federation does not provide basis for such a concept as a financial conglomerate. The Law on Banking Activities provides definitions of Banking Groups and Banking Holdings, The Law on Insurance activities - Insurance Groups (Table 1).

The activities of bank holdings are regulated not so strictly as of banking groups. The holdings are subject only to the notification of the megaregulator of the market - the Bank of Russia on the formation of a bank holding company and the establishment of its management company, disclosure of information, as well as reporting on the risks of the holding to the Bank of Russia.

The "insurance group" is a narrow concept and does not cover the spectrum of financial services offered by the financial conglomerate. Insurance groups are defined only in the Law on Insurance Activities (Zakon RF ot 27.11.1992 N 4015-1, red. ot 31.12.2017), but there are no additional regulator's requirements to them. Moreover, the transition to a risk-oriented approach in supervision of the insurance segment in the Russian financial market has not yet extended to insurance groups. The dissemination of the principles of the risk-based regulation system to the level of insurance groups is planned to be implemented with the improvement and achievement of certain maturity and established practices of applying a risk-based approach to regulating insurance organizations on an individual basis, as well as the corresponding development of the regulatory framework.

The Russian regulator of the insurance market of the Central Bank of Russia is pursuing a policy in line with international trends. To implement the regulation based on the principles of risk management, the Central Bank of Russia for the first time developed a Roadmap for the implementation of the "Main Directions for the Development of the Financial Market of the Russian Federation for the Period 2016-2018". 
Table 1. Types of Financial conglomerates

\begin{tabular}{|c|c|c|}
\hline $\begin{array}{c}\text { Corporate } \\
\text { structure }\end{array}$ & Definition/notion & Source: Legal regulation \\
\hline $\begin{array}{l}\text { Financial- } \\
\text { industrial } \\
\text { groups } \\
\text { (FIG) }\end{array}$ & $\begin{array}{l}\text { - the group of legal persons acting as the main and sub- } \\
\text { sidiary companies, or wholly or partly combined their } \\
\text { tangible and intangible assets (the participation system) } \\
\text { on the basis of an agreement on the establishment of a } \\
\text { financial - industrial group. The purpose - technologi- } \\
\text { cal or economic integration, investment activities for } \\
\text { increasing competitiveness and expanding the markets } \\
\text { for goods and services, increasing production effi- } \\
\text { ciency, creating new jobs. }\end{array}$ & $\begin{array}{l}\text { Expired in 2007; } \\
\text { Mentioned in the Civil Code of the } \\
\text { Russian Federation. }\end{array}$ \\
\hline $\begin{array}{l}\text { Banking } \\
\text { group }\end{array}$ & $\begin{array}{l}\text { - an association of separate legal entities (not admitted to } \\
\text { be a single legal entity), in which one legal entity or } \\
\text { several legal entities (members of a banking group) are } \\
\text { under the control or significant influence of one credit } \\
\text { organization (the parent credit organization of a bank- } \\
\text { ing group). }\end{array}$ & $\begin{array}{l}\text { Federal Law No. 395-1 of Decem- } \\
\text { ber 2, } 1990 \text { (as amended on Decem- } \\
\text { ber 31, 2017) "On Banks and Bank- } \\
\text { ing Activities" (as amended and } \\
\text { supplemented, effective from Janu- } \\
\text { ary 28, 2013). }\end{array}$ \\
\hline $\begin{array}{l}\text { Banking } \\
\text { holding }\end{array}$ & $\begin{array}{l}\text { - an association of separate legal entities (not admitted to } \\
\text { be a single legal entity), including at least one credit in- } \\
\text { stitution under the control of one legal person which is } \\
\text { not a credit institution (the parent organization of a } \\
\text { banking holding company), and (if any) other (non- } \\
\text { credit institutions) legal entities. persons who are under } \\
\text { the control or significant influence of the parent organi- } \\
\text { zation of the banking holding or who are members of } \\
\text { the banking groups of credit institutions participating in } \\
\text { the banking holding, provided that the share of banking } \\
\text { activities is at least } 40 \text { percent. }\end{array}$ & $\begin{array}{l}\text { Federal Law No. 395-1 of Decem- } \\
\text { ber 2, } 1990 \text { (as amended on Decem- } \\
\text { ber 31, 2017) "On Banks and Bank- } \\
\text { ing Activities" (as amended, } \\
\text { supplemented, came into force from } \\
\text { January 28, 2013). }\end{array}$ \\
\hline $\begin{array}{l}\text { Insurance } \\
\text { group }\end{array}$ & $\begin{array}{l}\text { - an association of legal entities that is not a legal entity, } \\
\text { in which one legal entity or several legal entities (here- } \\
\text { inafter referred to as the participants of the insurance } \\
\text { group) are under the control or significant influence of } \\
\text { one insurance organization (hereinafter - the parent in- } \\
\text { surance organization of the insurance group). }\end{array}$ & $\begin{array}{l}\text { Law of the Russian Federation No. } \\
4015-1 \text { of } 27 \text { November } 1992 \text { (as } \\
\text { amended on 31.12.2017) "On the } \\
\text { Organization of Insurance Business } \\
\text { in the Russian Federation" (as } \\
\text { amended and supplemented, came } \\
\text { into force from 28.01.2018). }\end{array}$ \\
\hline
\end{tabular}

During the implementation of the reform of the regulatory system in the financial market in 2013, the Bank of Russia was entrusted with the task of developing the main directions for the development of the financial market of the Russian Federation. According to Article 45.3 of the Federal Law of 10.07.2002 No. 86 FZ "On the Central Bank of the Russian Federation (Bank of Russia)", the Bank of Russia once every three years presents the draft guidelines for the development of the financial market in the State Duma (Plan meropriyatiy (dorozhnaya karta) Banka Rossii na 2016 god...). This document was approved by the Government of the Russian Federation and was considered at parliamentary hearings in the State Duma on 14.04.2016, after which it was approved on May 26, 2016 in the final version by the Board of Directors of the Bank of Russia. This document is unique for the financial market of the Russian Federation, as it has a "cross-sectoral character" and contains a description of the planned actions of the Bank of Russia for the development of all sectors of the financial market for the mediumterm period (Plan of measures (road map) of the Bank of Russia for 2016...).

In July 2016, the Bank of Russia published a Report for public consultations (Russian Federation Central Bank of the RF), in which for the first time it was ascertained that there are 314 informal conglomerates in the Russian Federation. When assigning a corporate structure (group) to a financial conglomerate the Central Bank of the Russian Federation uses the definition from the EU Directive No. 2002/87/EC) due to the absence of this definition in the Russian Federation legislation. Based on the Report and the comments received 
during its consideration, The Bank of Russia will develop regulatory documents (legislation) that will apply to holdings, management companies (MCs), parent non-resident companies, requirements to the risk management system, to capital, etc.

But the problem of setting up unified requirements for groups (holdings) of different sectors of the financial market remains unsolved.

The report confuses the concepts of Holding and financial conglomerate, which are supposed to be fixed by law. Meanwhile the regulator tries to introduce separate elements of regulation and supervision at the group level sectorally (banking, insurance sector), which, of course, is not a very good option for the new regulation. The main reason for putting forward increased requirements for Financial conglomerate is the cross-sectoral risks of bankruptcy of the firms that are members of the conglomerate (Table 2).

The concept of "bank holding", according to the document, will also apply to informal associations of credit and non-credit financial organizations that have the same owners. It is proposed to establish equal regulation for bank holdings and groups, which fully meets international approaches. Banks belonging to bank holdings, in addition to their own risks, also assume the risks associated with the activities of its other participants. Financial difficulties or loss of business reputation of one credit institution can lead to a decrease in the financial stability of other credit institutions - participants in such associations.

After amending the legislation, bank holdings will have to comply with mandatory standards, surcharges to capital adequacy standards, requirements for risk and capital management systems, and internal control. Heads of the headquarter organization of the banking holding will be subject to the same requirements for business reputation and qualifications, as for top managers of credit institutions. Supervision over the activities of these holdings will be entrusted to the Bank of Russia.

The document establishes the obligation of the bank holding owners, in which there are participants performing non-financial activities, to separate the banking and financial activities in the subholding and create a management company of the bank holding. At the same time, there is no requirement to transfer shares and stocks in financial organizations to the management company. The management company will be entrusted with the execution of all duties that must be performed by the holding's parent organizations, unless otherwise stipulated by federal laws. The same subholding should be created on the territory of the Russian Federation and in case the parent organization of the holding is located abroad.

Table 2. The Report identifies new forms of associations of the Russian financial market subjects

\begin{tabular}{|c|l|}
\hline & $\begin{array}{l}\text { A financial group is proposed to be an asso- } \\
\text { ciation of legal entities that is not a legal en- } \\
\text { tity as a whole, in which one or several legal } \\
\text { persons are under the control or significant } \\
\text { influence of one non-credit financial organi- } \\
\text { zation (head-quarters organization of a fi- } \\
\text { nancial group), except for cases when the } \\
\text { share of banking activities in a group is } 40 \% \\
\text { or more and such an association is recog- } \\
\text { nized as a bank holding. }\end{array}$ \\
\hline Under the financial holding company, it is \\
proposed to understand the non-legal entity \\
of the. Legal persons union, including at \\
least one non-credit financial organization \\
under the control of one legal person who is \\
not a credit and non-credit financial organi- \\
zation (parent organization of a financial \\
holding company), as well as other legal en- \\
tities that are under the control or significant \\
influence of the financial holding parent or- \\
ganization or who are members of the finan- \\
cial groups financial holding company. At \\
the same time, when a financial holding \\
company is formed, the share of non-credit \\
financial organizations of the respective type \\
in the activities of the whole holding should \\
be at least 40\% and be determined on the ba- \\
sis of the methodology of the Bank of Rus- \\
sia.
\end{tabular}

At the same time, it is necessary to establish a three-year transitional period for coming into force regulatory norms for supervision of credit institutions, banking groups and bank holdings. In particular, the requirements for the establishment of management bodies of the banking group, the bank holding company will be applied from January 1,2020 , and in terms of the regulation of banking holdings - from January 1, 2021.

\subsection{Identification of Finansial conglomerates in Lithuania}

The main feature of the financial markets formation in the Eastern Europe (apart from Russia) was the abolition of restrictions on the participation of non-residents in the capital of domestic insurance companies, banks, pension funds, etc. It 
occurred at the initial stage of market development and in fact ensured a complete victory of foreign over the national capital.

After joining the European Union in 2004, Lithuania, like other post-Soviet republics, faced the problem of the national financial market developing. In the course of reforms and state property privatization, a large number of financial institutions - banks, insurance companies, investment funds, etc. - have been created. After the formation of the banking and insurance sectors, the latter consolidation began at a rather rapid pace, accompanied by the expansion of foreign players, which radically changed the balance of power in the financial sector.

With the merger of national and international markets in the countries of Central and Eastern Europe, there has been a loss of national control over entire sectors of the economy, including the one over the financial market. The sphere of financial services has been seriously affected, since the rules of the World Trade Organization (WTO) require the equal access provision of private capital for any services and open international competition.

National insurance companies and banks faced the problem of survival. De facto, foreign insurers (open branches of European insurance companies) were able to give citizens and companies of "new emerging" markets the opportunity to use larger, longer and cheaper credit resources, as well as to implement better financial services.

Lithuania also found itself in a confluence of national and international markets. According to the Bank of Lithuania (Bank of Lithuania), there are 531 insurance companies in the country, but the national sovereignty was kept only by nine of them. With closer examination of the national companies list, one observes that they are subsidiaries of foreign financial conglomerates (PZU, SEB, AVIVA, ERGO). There are only four sovereign Lithuanian undertakings - Lietuvos draudimas, Bonumpublicum, Gjensidige, lamantinas.lt. These companies occupy narrow niches in cargo insurance, liability insurance of 14 branches of the EU countries' companies. 497 insurance undertakings provide insurance services in the territory of Latvia without forming a branch.

Therefore, the definition of a possible interstate supervision system and control architecture, is by no means a trivial task. The institutional structure of regulation is very important, since it can influence the overall financial market functioning through the overall effectiveness of the regulatory system and the interaction between its components. Moreover, developing norms for regulation of such complex financial structure as a conglomerate, there are also a lot of not clearly defined objectives of regulation, conflicts of interest, etc. In this aspect, the questions arise how to organize the interconnection of different interests, whether it is possible to reduce the costs of regulation in a single supervisory body or in different governmental agencies. There is no answer to this question.

The architecture of financial supervision in the European Union is based on an industry model with separate functional regulators for the banking, insurance sectors and the securities market and is not adequate to modern requirements of the financial market supervision. In addition to prudential supervision, there is a need to protect rights and interests of complex financial services' consumers. Moreover, a paradoxical situation has developed. Financial conglomerates, combining banking and insurance activities, account for about a third of the banking and insurance sectors in Europe (Schoenmaker \& Véron, 2017), they are subject to increased capital requirements, regulation and supervision are carried out on a consolidated basis (Towards an EU directive..., 2000), but separately by a banking or insurance regulator. The combined regulation would strengthen prudential surveillance of these conglomerates. The same problem is observed at the national level in Lithuania.

The Bank of Lithuania in the country is the regulator, but the aggregate statistical data on insurance groups controlled in accordance with Directive 2009/138/EB are not published on the site, as the Bank of Lithuania is not responsible for supervision of the financial market insurance sector on a group basis. At the same time, the banking sector is regulated on a consolidated basis.

Lithuania adopted the Law, which gives the identification of the financial conglomerate at the national level as follows:

"Financial conglomerate" shall mean a group or subgroup which meets the following conditions:

1) a regulated entity is at the head of the group or at least one of the subsidiaries in the group is a regulated entity;

2) where there is a regulated entity at the head of the group, it is either: a parent undertaking of an entity in the financial sector; an entity which holds a participation in an entity in the financial sector; an entity which, though not connected with one or more other entities in the financial sector by a relationship within 
the meaning of paragraphs 6 and 19 of this Article is, nevertheless, managed on a unified basis pursuant to a contract concluded with that entity or provisions in the memorandum or articles of association of those entities or the administrative, management or supervisory bodies of that entity and of one or more other entities consist for the major part of the same persons in office during the financial year and until the consolidated accounts are drawn up;

3) where there is no regulated entity at the head of the group, but the group's, activities mainly occur in the financial sector within the meaning of Article 3(1) of this Law;

4) at least one of the entities in the group is within the insurance sector and at least one is within the bank or investment services sector;

5) the consolidated and/or aggregated activities of the entities in the group within the insurance sector and the consolidated and/or aggregated activities of the entities within the banking or investment services sector are both significant within the meaning of Article 3(2) or (3), except where the relevant competent authorities decide not to regard the group as a financial conglomerate within the meaning of article 3(4) of this Law.

\section{Conclusions}

1. Financial conglomerate as an integrated institution and requires a special attention from financial market regulators. Activities in this direction is underway. First, it is necessary to outline the perimeter of the organizations that can be included into the conglomerate. This is complicated by the fact that the conglomerate structure is unstable; the relationship between the companies is weak.

2. Identification of financial conglomerate in Lithuania is based on EU practices. Institutional structure of regulation and supervision is in the process of development. The same is for Russia. Regulators in both the countries pay attention to conglomeration process mostly in banking sector of national financial market and emerging insurance groups are currently out of sight.

3 . Financial conglomerates, combining banking and insurance activities, account for about a third of the banking and insurance sectors in Europe (including the EU countries and the UK), they are subject to increased capital requirements, regulation and supervision are carried out on a consolidated basis, but separately by a banking or insurance regulator. The problem is also observed at the national level in Russia and Lithuania. The consolidated regulation by type of Japanese would strengthen prudential surveillance of these conglomerates.

4. The institutional structure of regulation is very important, since it can influence the overall financial market functioning through the overall effectiveness of the regulatory system and the interaction between its components. Moreover, developing norms for regulation of such complex financial structure as a conglomerate, don't include clearly defined objectives of regulation, conflicts of interest consideration, etc. In this aspect, the questions arise how to organize the interconnection of different interests, whether it is possible to reduce the costs of regulation in a single supervisory body or in different governmental agencies. The risks are higher for small emerging economies like Lithuania where costs of regulation could play a crucial role for the overall economy.

5. The architecture of financial supervision in the European Union is based on an industry model with separate functional regulators for the banking, insurance sectors and the securities market and is not adequate to modern requirements of the financial market supervision. In addition to prudential supervision, there is a need to protect rights and interests of consumers. The latter is under the close eye of the US regulator.

\section{References}

Akio, M. (2007). Sdelano v Yaponii (2-e izd., 289 s.). Mockva: Al'pina Biznes Buks.

Allen, F., \& Santomero, A. M. (2001). What do financial intermediaries do?. Journal of Banking \& Finance, 25(2), 271-294.

https://doi.org/10.1016/S0378-4266(99)00129-6

Amel, D., Barnes, C., Panetta, F., \& Salleo, C. (2004). Consolidation and efficiency in the financial sector: A review of the international evidence. Journal of Banking \& Finance, 28(10), 2493-2519. https://doi.org/10.1016/j.jbankfin.2003.10.013

Atkinson, A. B., \& Micklewright, J. (1992). Economic transformation in Eastern Europe and the distribution of income. Cambridge University Press.

Bank of England. (2003, December). Financial stability review (p. 92). Retrieved from http://www.bankofengland.co.uk/publications/ fsr/2003/fsr15art3.pdf

Bank of Lithuania. (2018). The official website of the Bank of Lithuania. Retrieved from http://www.lb.lt/en

Bank Rossii. [n.d.]. Plan meropriyatiy (dorozhnaya karta) banka Possii na 2016 god po realizatsii osnovnykh napravleniy razvitiya finansovogo rynka rossiyskoy federatsii na period 2016-2018 godov“. Retrieved from https://www.cbr.ru/StaticHtml/File/11106/map. pdf 
Basic Concepts concerning Financial Conglomerates Supervision. (1998). Financial Services Agency Organization Rules (Ordinance No. 81 of Prime Minister's Office). Retrieved from http://www.fsa.go.jp/en/refer/ guide/conglomerate/01.html

Beck, T., \& Casu, B. (Eds.). (2016). The Palgrave Handbook of European Banking. Palgrave Macmillan. https://doi.org/10.1057/978-1-137-52144-6

Berger, A. N., Hasan, I., \& Zhou, M. (2010). The effects of focus versus diversification on bank performance: Evidence from Chinese banks. Journal of Banking \& Finance, 34(7), 1417-1435. https://doi.org/10.1016/j.jbankfin.2010.01.010

Berkshire Hathaway Inc. (2010, February 26). Annual Report. Form 10-K, at 28. Retrieved from https://www. sec.gov/Archives/edgar/data/1067983/0001193125 15070966/d820461d10k.htm

Bhatia, M. A. V. (2007). New landscape, new challenges: Structural change and regulation in the US Financial sector (EPub). (No. 7-195). International Monetary Fund.

Brealey, R. A., Myers, S. C., Allen, F., \& Mohanty, P. (2012). Principles of corporate finance. Tata McGraw-Hill Education.

Brown, E. F. (2005). E Pluribus Unum-Out of Many, One: Why the United States needs a single financial services agency. University of Miami Business Law Review, 14(1), 16. Retrieved from https://repository. law.miami.edu/umblr/vol14/ iss $1 / 2$

Chaffee, E. C. (2010). The Dodd-Frank Wall Street Reform and Consumer Protection Act: A failed vision for increasing consumer protection and heightening corporate responsibility in international financial transactions. American University Law Review, 60(5), 1431. Retrieved from http://digitalcommons.wcl.american.edu/cgi/viewcontent.cgi? article $=1633 \&$ context $=$ aulr

Directive 2002/87/EC of the European Parliament and of the Council of 16 December 2002 on the supplementary supervision of credit institutions, insurance undertakings and investment firms in a financial conglomerate and amending Council. Retrieved from http://eur-lex.europa.eu/legal-content/GA/TXT/?uri=CELEX:32002L 0087

Directive 2009/138/EC of the European Parliament and of the Council of 25 November 2009 on the taking-up and pursuit of the business of Insurance and Reinsurance (Solvency II). Retrieved from https://eur-lex.europa. eu/legal-content/EN/TXT/PDF/?uri=OJ:L:2009:335: FULL\&from $=\mathrm{EN}$

Dodd-Frank Wall Street Reform and Consumer Protection Act, Pub. L. No. 111-203, §§ 115(a), 121(a), 155(d), 163(b), 165(j), 166(a), 172(a), 210(o)(1)(A), 124 Stat. 1376 (2010). Retrieved from https://www.sec.gov/ about/laws/wallstreetreform-cpa.pdf

Duflo, E., \& Saez, E. (2002). Participation and investment decisions in a retirement plan: The influence of colleagues' choices. Journal of Public Economics, 85(1): 121-148. https://doi.org/10.1016/S0047-2727(01)00098-6

Elyasiani, E., Staikouras, S. K., \& Dontis-Charitos, P. (2016). Cross-industry product diversification and contagion in risk and return: The case of Bank-Insurance and Insurance-Bank Takeovers. Journal of Risk and Insurance, 83(3), 681-718. https://doi.org/10.1111/jori.12066
Federal Law No. 208-FZ of December 26, 1995 (as amended on December 31, 2017) “On Joint Stock Companies". Retrieved from http://www.consultant.ru/document/ Cons_doc_LAW_8743/fca351034948ee4a2889d0f3c0 $8595 \overline{\mathrm{a}} 793 \overline{3} \mathrm{ea} 9 \mathrm{f} 2 /$

Final Report on the Peer Review on Freedom to Provide Services. (2016). Publication of Outcomes. EIOPA-BoS16-072 29 April 2016. Retrieved from https://eiopa.europa.eu/Publications/Reports/EIOPA_Peer_Review FPS_Final_Report_Publication_Outcomes_20160429 cl.pdf

Financial Services Agency. (2005, June). Guideline for Financial Conglomerates Supervision (Japan). Retrieved from https://www.fsa.go.jp/news/newse/e20050812. pdf

Global Fortune 500 and CIA World Factbook data. (2016). Retrieved from https://blogs.worldbank.org/publicsphere/world-s-top-100-economies-31-countries-69corporations;

http://www.globaljustice.org.uk/news/2016/sep/12/10biggest-corporations-make-more-money-most-countries-world-combined

Goddard, J., Molyneux, P., Wilson, J. O., \& Tavakoli, M. (2007). European banking: An overview. Journal of Banking \& Finance, 31(7), 1911-1935. https://doi.org/10.1016/j.jbankfin.2007.01.002

Hartmann, P., Maddaloni, A., \& Manganelli, S. (2003). The Euro-area financial system: Structure, integration, and policy initiatives. Oxford Review of Economic Policy, 19(1), 180-213. https://doi.org/10.1093/oxrep/19.1.180

Kalemli-Ozcan, S., Manganelli, S., Papaioannou, E., \& Peydró, J. L. (2008, November). Financial integration and risk sharing: The role of monetary union. In Prepared for the $5^{\text {th }}$ European Central Banking Conference on the Euro at Ten: Lessons and Challenges.

Kose, M. A., Prasad, E., Rogoff, K., \& Wei, S. J. (2009). Financial globalization: A reappraisal. IMF Staff $\mathrm{Pa}-$ pers, 56(1), 8-62. https://doi.org/10.1057/imfsp.2008.36

Kushmeider, R. M. (2005). The US federal financial regulatory system: restructuring federal bank regulation. FDIC Banking Review, 17(4).

Kuznetsova, N. P., Pisarenko, Zh. V., \& Chernova, G. V. (2016). Financial market institutions competitiveness and financial convergence. New Challenges of Economic and Business Development, 442.

Kuznetsova, N. P., \& Chernova, G. V. (2001). Konvergentsiya v sfere bankovskikh uslug. Vestnik $S P b G U$, $5(23), 129-136$

List of Financial Conglomerates. (2017). Financial conglomerates with head of group in the EU/EEA. Retrieved from https://esas-joint-committee.europa.eu/Publications/Guidelines/List $\% 20$ of\%20financial\%20conglomerates\%202017.pdf

Ozcan, K., Manganelli, S., Papaioannou, E., \& Peydró, J. L. (2008). Financial integration and risk sharing: the role of Monetary Union, in The Euro at Ten - Lessons and Challenges. In Proceedings of the $5^{\text {th }}$ European Central Banking Conference, 16-14 November 2008, ECB. Retrieved from http://www.openaccess.city.ac. uk/ 1116/1/

Peleckiene, V., Peleckis, K., \& Dudzevičiūtè, G. (2011). New challenges of supervising financial conglomerates. Intellectual Economics, 5(2), 298-311.

Plan of measures (road map) of the Bank of Russia for 2016 to implement the main directions of the development of the financial market of the Russian Federation for the 


\section{FINANCIAL CONGLOMERATE IDENTIFICATION BY FINANCIAL MARKETS REGULATORS: CASE OF DEVELOPED AND EMERGING MARKET ECONOMIES}

period 2016-2018. Retrieved from http://www. cbr.ru/statichtml/file/12158/map-2016 e.pdf

Russian Federation Central Bank of the RF. (2016). The official site of the single megaregulator of financial markets in the Russian Federation Central Bank of the RF. Retrieved from http://www.cbr.ru/analytics/ppc/report holding 1606.pdf

Schmid, M. M., \& Walter, I. (2009). Do financial conglomerates create or destroy economic value?. Journal of Financial Intermediation, 18(2): 193-216. https://doi.org/10.1016/j.jfi.2008.07.002

Schoenmaker, D., \& Véron, N. (2016). European banking supervision: the first eighteen months. Bruegel Blueprint Series, 25.

Schoenmaker, D., \& Véron, N. (2017). EBA relocation should support a long-term 'Twin Peaks' vision'. Bruegel Blog, 5.
Staikouras, S. K. (2006). Business opportunities and market realities in financial conglomerates. The Geneva $\mathrm{Pa}$ pers on Risk and Insurance-Issues and Practice, 31(1), 124-148.

https://doi.org/10.1057/palgrave.gpp.2510060

Towards an EU directive on the prudential supervision of financial conglomerates. Consultation Document. MARKT/3021/2000. MARKT/3021/00-EN. European Commission internal market directorate general. Financial Conglomerates Directive, FICOD. Retrieved from http://ec.europa.eu/internal_market/financialconglomerates/docs/consult_en.pdf

Zakon RF ot 27.11.1992 N 4015-1 (red. ot 31.12.2017) "Ob organizatsii strakhovogo dela $v$ Rossiyskoy Federatsii” (s izm. i dop., vstup. v silu s 28.01.2018). Stat'ya 6, p. 9. 